\title{
Disclosure Practices of Foreign Companies Interacting with U.S. Markets
}

\section{Citation}

Khanna, Tarun, Krishna G. Palepu, and Suraj Srinivasan. "Disclosure Practices of Foreign Companies Interacting with U.S. Markets." Journal of Accounting Research 42, no. 2 (May 2004).

\section{Published Version}

10.1111/j.1475-679X.2004.00146.x

\section{Permanent link}

http://nrs.harvard.edu/urn-3:HUL.InstRepos:29660925

\section{Terms of Use}

This article was downloaded from Harvard University's DASH repository, and is made available under the terms and conditions applicable to Other Posted Material, as set forth at http:// nrs.harvard.edu/urn-3:HUL.InstRepos:dash.current.terms-of-use\#LAA

\section{Share Your Story}

The Harvard community has made this article openly available.

Please share how this access benefits you. Submit a story.

\section{Accessibility}




\title{
Disclosure Practices of Foreign Companies Interacting with U.S. Markets
}

\author{
Tarun Khanna \\ Harvard Business School \\ Boston, MA 02163 \\ tkhanna@hbs.edu \\ Krishna Palepu \\ Harvard Business School \\ Boston, MA 02163 \\ kpalepu@hbs.edu \\ Suraj Srinivasan \\ Harvard Business School \\ Boston, MA 02163 \\ susrinivasan@hbs.edu
}

December 2003

\begin{abstract}
We would like to thank Standard \& Poor's and Amra Balic, Sandeep Patel, George Dallas, and Ian Byrne for assistance with the Transparency and Disclosure survey. We would also like to thank Dennis Campbell, Gregory Miller, Edward Riedl, the editor (Ray Ball), an anonymous referee, Brian Bushee (the discussant), and participants at the Work in Process seminar at Harvard Business School, the 2003 Journal of Accounting Research Conference, and the Burton Workshop at Columbia Business School. The research assistance of Chris Allen, Sarah Eriksen, Bryan Lincoln, Kathleen Ryan, Sarah Woolverton, and James Zeitler is gratefully acknowledged. We are grateful for the funding of this research by the Harvard Business School. We thank I/B/E/S for providing data on analyst following.
\end{abstract}




\title{
Disclosure Practices of Foreign Companies Interacting with U.S. Markets
}

\begin{abstract}
We analyze the disclosure practices of companies as a function of their interaction with the U.S. markets for a group of 794 firms from 24 countries in Asia-Pacific and Europe. Our analysis uses the Transparency and Disclosure scores developed recently by Standard \& Poor's. These scores rate the disclosure of companies from around the world using U.S. disclosure practices as an implicit benchmark. Results show a positive association between these disclosure scores and a variety of market interaction measures, including US Listing, US investment flows, export to and operations in the US. Trade with US, however, has an insignificant relationship with the disclosure scores. Our empirical analysis controls for the previously documented association between disclosure and firm size, performance, and country legal origin. Our results are broadly consistent with the hypothesis that cross-border economic interactions are associated with similarities in disclosure and governance practices.
\end{abstract}




\section{Introduction}

The question we seek to answer in this paper is: are cross-border economic interactions with U.S. capital markets, labor markets, and product markets associated with adherence to U.S. corporate disclosure standards and practices?

Two strands of literature motivate our work. The first is the literature in economics and law that discusses the general impact of globalization on the convergence of governance practices around the world. One view in this literature holds that the force of global competition will result in the complete convergence of governance systems across countries (Hansmann and Kraakman [2000]). The polar opposite perspective holds that path dependence and complementarities in governance mechanisms will prevent such convergence (Bebchuk and Roe [1999]). The intermediate perspective suggests that there may be partial convergence among groups of countries that interact closely through market transactions (Khanna, Kogan, and Palepu [2002]).

Following this intermediate perspective, we look at the interactions between international companies and U.S. markets. We also look at only one element of corporate governance, namely disclosure and transparency. As Bushman and Smith [2001] point out, financial reporting and disclosure is an important component of a corporate governance system since it allows investors and other outside parties to monitor firm performance and contractual commitments. While there are several other critical elements besides financial reporting in a corporate governance system, such as the Board of Directors, shareholder rights, and top management compensation, we believe that this narrow focus is likely to be useful in deepening our understanding of the broader question of the impact of globalization on corporate governance. 
A second strand of work, from accounting research, also motivates our study. There is accounting research that specifically examines the impact of financial market interactions on firms' disclosure choices. For example, in a contemporaneous study, Bradshaw, Bushee, and Miller [2002] conclude that foreign firms that provide financial statements with greater conformity to U.S. GAAP exhibit higher levels of U.S. institutional ownership. In another study, Lang, Raedy, and Yetman [2003] find that in terms of local GAAP earnings cross listed firms appear to be more similar to U.S. firms than other firms in their local markets. Our study seeks to extend this literature - unlike prior studies examining the impact of disclosure from a single type of market interaction we comprehensively examine the relation between disclosure and all market interactions - product, labor, and financial markets.

Our empirical analysis uses a new database on international corporate disclosure the Transparency and Disclosure survey developed by Standard and Poor's. These recently released scores provide us with a measure of corporate annual report disclosures. Our sample consists of 794 firms from 24 countries in Asia-Pacific and Europe. We use a variety of firm-level and country-level metrics to measure the degree of interaction with the U.S. capital, product, and labor markets. The sample consists of firms from a wide range of institutional contexts - China with very little resemblance to the U.S. institutional context to U.K. with a great deal of similarity to the U.S. institutional context. The degree of interaction with the U.S. markets also varies widely, with some firms being listed on the U.S. capital markets, and with significant U.S. operations, and other firms with little or no interaction with the U.S. markets. 
Our empirical tests examine the relationship between market interaction variables and the transparency and disclosure measures for the sample firms, after controlling for a variety of other variables known to have an impact on firms' disclosure. Our results show that, on average, greater market interaction with the U.S. is associated with greater similarities to U.S. disclosure practices.

Our correlational evidence does not, of course, allow for causal inferences. For example, we do not know whether the interactions with U.S. markets lead our sample firms to adopt U.S. disclosure practices, or whether the adoption of U.S. disclosure practices enables the sample firms to become more active in the U.S. factor and output markets. Also, our measure of disclosure does not allow us to distinguish between the quantity and the quality of disclosure, or between voluntary and mandatory disclosures. Finally, since we employ a sample preselected by Standard and Poor's for inclusion in their indices, our conclusions are not based on a random sample drawn from these countries. Given these limitations, our findings should be interpreted with caution.

We review relevant prior literature and develop testable hypothesis in Section 2. Section 3 contains description of the S\&P Transparency and Disclosure data and the sample. Section 4 provides a description of the empirical proxies for the U.S. interaction and control variables. Section 5 provides the results and Section 6 concludes.

\section{Hypotheses and related literature}

Globalization and similarities in corporate governance across countries has been the subject of much interest in academic literature. The idea of convergence in 'form', postulates that efficiency considerations and, implicitly, some form of global 
competition, will force all nations to ultimately adopt the same corporate governance system (Hansmann and Kraakman [2000]). The 'functional convergence' perspective (Gilson [2000]) presents the idea that each country's institutions are sufficiently flexible so that the key functions of corporate governance can be largely achieved within the different institutional arrangements in each country. At the other end is the view that path dependence and complementarities in economic systems has led different economies to very different corporate governance systems, that even the force of global competition will not easily dislodge (Bebchuk and Roe, [1999]).

The role of global competition in factor and output markets is at the core of these arguments. The role of capital markets is often emphasized - for example the idea that global institutional investors, largely originating from the U.S., will compel firms, that seek their funds, to adopt corporate governance standards with which they are familiar. Coffee [1999] presents the idea of a sorting of a country's firms. Higher quality firms will list in high quality capital markets abroad and the lower quality ones remain in the home country, with resultant pressure on the local capital markets to upgrade. The role of product and labor market competition is less emphasized. In an empirical study, Khanna, Kogan and Palepu [2002] examine partial convergence between groups of countries that interact with each other through various types of product, labor and capital market transactions. They find that pairs of economically interdependent countries adopt similar corporate governance practices especially if these countries are also economically developed.

Given the wide scope of the corporate governance system we take a focused view in this paper and examine one component of the governance system - financial reporting 
and disclosure. In doing so we follow a model similar to that expressed in Bushman and Smith [2001]. They posit a governance role for financial accounting information that arises from the use of information for project identification, monitoring project selection, monitoring managerial expropriation, reducing information asymmetry between investors, and from use by current and potential managers to decide on human capital investment.

In our analysis, we focus on total disclosures of firms, which consists of both mandated and voluntary disclosures. In an international context, we believe that this is the appropriate focus because country-level mandatory disclosures themselves are to some extent voluntary choices by the country regulators. Thus, a country might choose a disclosure regime with a view to facilitating certain types of market interactions between its companies and companies or investors in another country.

We now develop our hypotheses for different types of market interactions. Capital market interaction: Greater capital market interaction can take place in two ways. First, companies' may cross-list in the U.S. capital markets as American Depository Receipts, or choose one of the U.S. stock exchanges as their primary listing exchange. Second, U.S. investors can invest in companies in markets around the world.

The effect on disclosure when companies list their shares as equity or as depositary receipts on U.S. stock exchanges is direct. When companies list on U.S. exchanges, they have to follow the stock exchange and SEC requirements on disclosure. While there are many disclosure exemptions for foreign companies from the domestic rules, the level of disclosure required is generally quite high. Level-II and Level-III ADR's have to follow U.S. SEC rules for registration and file Form 20-F providing 
reconciliation of financial statements with U.S. GAAP (Karolyi [1998]). Hence we can expect firms that list in the U.S. are more likely to adopt U.S. disclosures practices compared to those that do not.

Disclosure can also be affected due to the U.S. portfolio investment in the home country of an international company in a few ways. Managers may voluntarily increase disclosure to attract U.S. investors. Alternatively, foreign investors from countries with better disclosure and governance standards may demand greater disclosure and better governance in companies and countries in which they have invested. ${ }^{1}$ Consistent with both these arguments, Bradshaw, Bushee and Miller [2002], in a study contemporaneous to this research, show that firms with greater level of conformity with U.S GAAP exhibit greater levels of U.S. institutional ownership. Finally, countries may improve their mandatory disclosure rules and governance requirements in order to market themselves to foreign institutional investors. For example, China and Malaysia recently introduced mandatory quarterly reporting in their overhaul of governance and disclosure requirements. Companies and industry associations may also lobby their governments for such improvements. ${ }^{2}$

From the foregoing discussion we predict a positive association between the extent of capital market interaction with the U.S. and the adoption of U.S. disclosure practices. In our analysis, we test this directional hypothesis against a null hypothesis of no association.

\footnotetext{
${ }^{1}$ As an example, Tiger Fund forced SK telecom, a South Korean firm belonging to the SK group, to abandon shareholder unfriendly practices.

${ }^{2}$ At a time when Indian regulations prohibited companies from distributing employee stock options, Infosys and rest of the software industry in India lobbied the Indian government to change the regulations. Khanna and Palepu [2001]
} 
Product market interaction: We are not aware of any prior studies that examine, either theoretically or empirically, the relationship between cross-border product market interaction and corporate disclosure. ${ }^{3}$ It is possible to make economic arguments that suggest either a positive or negative association between cross-border product market interaction and disclosure. Higher U.S. product market interaction can be associated with greater convergence to the U.S. disclosure regime. Companies and countries that wish to integrate themselves into the U.S. marketplace may find that the costs of doing business are greater if their disclosures do not conform to U.S. practices. Customers may need financial information to assess the long-term viability of their suppliers. Suppliers may not be willing to extend credit when they do not have adequate basis to judge a firm's credit worthiness. Conformance to U.S. practices makes it easier for U.S. customers and suppliers to make such a determination.

The effect on disclosure of greater product market integration across countries also depends on the nature of industrial specialization that results from such integration. International trade theory suggests that countries tend to specialize in different industries and sectors where their factor endowments provide them with a greater competitive advantage. If different industries and sectors have different governance and disclosure

\footnotetext{
${ }^{3}$ Prior papers have studied disclosure in the presence of proprietary costs i.e. the cost incurred when information is useful to competitors, and find that proprietary costs act to lower the level of disclosure (for example Verrechia [1983, 1990], Wagenhofer [1990], Hayes and Lundholm [1996]). Other papers have found the effect of competition on disclosure depends on the particular strategic context (for example: Darrough and Stoughton [1990], Darrough [1993], Newman and Sansing [1993], Gigler [1994], Pae [2002]). Firms may disclose less when they compete on price since the cost of capital benefit from increased disclosure is lower than proprietary costs incurred. However, when they compete on capacity, they may disclose more to attract capital at lower costs (Shin [2002]). This literature is somewhat relevant for our research. However, all these studies deal with the interaction between product market competition and voluntary disclosure, whereas our study focuses on total disclosure - both mandated and voluntary making it difficult to make predictions for our study based on this literature.
} 
needs, then we will not observe greater similarity in disclosure practices between countries that trade with each other extensively.

The degree of association between product market interaction and adoption of U.S. disclosure practices is, therefore, unclear. We therefore test the following null hypothesis against a non-directional alternate hypothesis: there is no association between the extent of product market interaction and adoption of U.S. disclosure practices.

Labor market interaction: The effect of increased labor market interactions on disclosure has also not been studied in prior research. Heightened interaction with the U.S. labor markets can be associated with greater convergence to U.S.-style disclosure for several reasons. First, companies seeking to attract talent from the U.S. labor market may be motivated to provide information so that prospective employees can assess the risk and benefits of the employment opportunities being offered. Further, such information may need to be similar to disclosures provided by U.S. companies to facilitate comparison. Second, interaction with the U.S. markets creates a pool of managers who have worked in a system of U.S. standards of disclosure. If these managers carry home with them practices they find effective in the U.S. environment, this may have a supply side effect on the amount of disclosure.

In some industries, improved corporate disclosure may be the response to increasing pressure to retain a talented labor force in a market where talent can move across borders. For example, companies in the software industry across the world risk losing talented engineers and programmers to U.S. companies since the talent in this industry is fairly mobile across national borders. We therefore test the null hypothesis against the following directional alternate hypothesis - there is a positive association 
between the extent of labor market interaction and the adoption of U.S. disclosure practices.

\section{Data}

To measure a firm's level of disclosure practices, we rely on a new data set recently released by Standard and Poor's. This data set provides standardized scores of disclosure for a large number of firms outside the U.S., using an implicit U.S. disclosure benchmark. For measures of interaction with the U.S. factor and output markets, we hand collect a variety of proxies either at the country or company level from several data sources.

\section{1. Standard and Poor's Transparency and Disclosure Data}

\section{Description of the Dataset}

We use a newly released dataset on corporate disclosures in our analysis, so we begin with a detailed description of this data set. In 2002, Standard and Poor's (S\&P) released the results of their Transparency \& Disclosure (T\&D) survey for companies in various countries around the world. S\&P describe the rankings as "an evaluation of the public disclosure practices of companies in various markets around the world." ${ }^{4}$

S\&P have evaluated the disclosure score by examining company annual reports and standard regulatory filings for disclosure of 98 specific items. One point is awarded when information on an item is available. The results from the 98 questions are then converted into a percentage and translated into scores from 1 to 10 with a higher score indicating greater disclosure. A percentage of 91 to 100 would give the company a score of 10 and a percentage of 11 to 20 would give a company a score of 2 . In our sample,

\footnotetext{
${ }^{4}$ The information in this section is drawn from Standard and Poor's (2002).
} 
scores range from 1-9, i.e. there are no companies that have percentage values from 91100.

The questions used for scoring are provided in Appendix 1. The questions are divided by S\&P into three broad categories: Financial Transparency and Information Disclosure (35 items), Board and Management Structure and Process (35 items) and Ownership Structure and Investor Relations (28 items). Almost all the items on the list either correspond to either mandatory disclosures in the U.S., or perceived best practices in U.S. corporate disclosure. As a result, we believe that the scoring uses an implicit U.S. benchmark, and assesses the extent to which companies around the world have adopted U.S. disclosure practices.

Financial Transparency and Disclosure (Financial) consists of 35 questions that try to assess whether information provided by the company will enable stakeholders to evaluate the financial condition and future viability of the company. These include information on the quality of accounting standards used in the preparation of financial statements (eg: U.S. GAAP or IAS), frequency of publication of financial statements (eg: quarterly or annual), extent to which aggregated and disaggregated disclosures are provided (eg: consolidated financial statements, segment data, information on affiliates in the firm owns minority stake, related party transactions), key accounting policies (eg: asset valuation and depreciation), disclosure on auditors (eg: identity, audit fees, and nonaudit fees), disclosure on business (eg: nature of business, physical statistics, corporate strategy), and management analysis and forecasts (eg: specific performance ratios, investment plans, earnings forecasts, industry trends). 
Board and Management Structure and Processes (Governance) consists of 35 questions. These range from board composition (eg: number of directors, names and background information on directors, whether or not the directors are independent), board committees (eg: information on audit, compensation and nominating committees), board compensation (eg: directors' salaries), top management composition (eg: names, background), top management compensation (eg: salary levels, specifics of performancebased compensation plans), and top management shareholdings.

Ownership Structure and Investor Rights category (Ownership) consists of 28 questions regarding the composition of shareholdings in a company (eg: number and identify of shareholders who own $5 \%$ or more shares each, identity of top 10 shareholders, percentage of cross-ownership), description of the equity claims against the company (eg: description of share classes), details of shareholder rights (eg: procedure for putting proposals at shareholder meeting and the way shareholders nominate directors to the board).

The subsection scores are also derived in the same way as the overall scores, by awarding one point for each item disclosed, and zero otherwise, and summing up the total points for all the questions in each subsection. S\&P has made available publicly the over all scores and the sub section scores but not the detailed item-by-item scores.

Several comments on Standard and Poor's methodology in computing scores are in order. First, while the scores could in theory measure the level of disclosure against a global benchmark, we believe that in reality they measure disclosure levels with respect to an implicit U.S. benchmark. This is substantiated by the fact that a vast majority of the 98 questions included in the scoring process are based on U.S. best practices. As a 
result, as we show below, U.S. companies are on average have higher scores than other companies. We therefore feel more comfortable using the scores as an index of convergence to the U.S. disclosure practices, rather than as an absolute measure of disclosure level.

Second, the scores measure whether or not a particular financial statement item or governance mechanism is disclosed, rather than evaluating the quality of the disclosure itself, or whether or not a particular governance mechanism is optimal. The scores are, therefore, a quantitative assessment of the disclosure practices of a company. They are not a qualitative indicator of the value of that information.

Third, the items used for scoring do not distinguish between mandatory and voluntary disclosures in the sample countries. Therefore any analysis using these scores cannot discriminate between mandatory and voluntary disclosures. Finally, while S\&P analysts group the questions into sub-categories - financial, governance, and ownership these categories do not appear to represent a "clean" grouping of questions. For example, some items classified under ownership category, such as number of shares outstanding, can also be thought of as a financial reporting item. Since we do not have access to data pertaining to individual questions, but only to aggregate scores in each category, we are constrained to use S\&P's grouping of items, rather than create our own grouping. As a result of this limitation, while we report descriptive data on the subgroup scores for our sample firms, we use only the overall disclosure score, and as a subsidiary dataset, the scores for the financial transparency subgroup, in our multivariate analysis.

In a conceptual sense, the $\mathrm{S} \& \mathrm{P}$ disclosure score is similar to the measure used by Botosan [1997] who measures disclosure directly by examining a comprehensive set of 
disclosures in annual reports and constructs a disclosure index. This measure is also similar to the CIFAR (Center for International Financial Analysis and Research) disclosure scores used in prior papers (for example La Porta et al. [1998], Hope [2002], Rajan and Zingales [1998], Bushman et al. [2003]). ${ }^{5}$ The CIFAR scores were created by examining annual reports for the omission or inclusion of 90 annual report items.

Some prior papers have used analysts rating of disclosure (for example Lang and Lundholm [1993, 1996], Healy et al. [1999]) to proxy for firm level disclosure scores. Khanna et al. [2002] use analyst ratings of firm level corporate governance practices. One advantage of scoring from financial reports is that, unlike an analyst's subjective assessment of disclosure, these are an objective assessment of disclosures. The drawback resulting from the methodology is that while the $\mathrm{S} \& \mathrm{P}$ scores allot equal weights to every item on the list, some disclosure items may be more important in reality than others.

\section{Sample and Descriptive Statistics}

The sample used in this study consists of all the companies covered in the four Transparency and Disclosure surveys covering companies in Japan S\&P/Topix Index, S\&P Asia Pacific 100 Index, S\&P IFC Emerging Asia Index and the Europe 350 Index a total of 814 companies in 32 countries. We drop all countries that have less than 5 companies in the sample. This results in 794 companies in 24 countries. This is the sample used in the analysis.

The sample coverage varies across countries. Japan with 150 companies and U.K with 127 companies are the most represented countries in the sample. The least

\footnotetext{
${ }^{5}$ CIFAR scores are not available beyond 1995 when the last edition of the International Accounting and Auditing Trends was published.
} 
representation is from Denmark and Portugal with 6 and 7 companies each. According to S\&P, the scores are based on the latest reports available to them during the survey. The annual reports used are from the year 2001 for Japan and for countries in Europe and from year 2000 for all other countries. Based on the Global Industry Classification system used by S\&P, the sample comes from 10 broad industry categories: Consumer Cyclicals (14.5\%), Consumer Stable (7.4\%), Energy (2.0\%), Financial (21.6\%), Healthcare (3.6\%), Industrials (17.8\%), Information Technology (12.02\%), Materials (10.26\%), Telecommunications (5.4\%), and Utilities (5.4\%). As can be seen, except for Financial firms, there is no significant concentration of sample firms in any one industry. One limitation of the sample is that the firms represent a group of companies preselected by S\&P for inclusion in indices, probably because they are the most prominent firms of interest to international investors. These firms are, therefore, unlikely to be a random sample of companies. In particular, since S\&P is based in the US, its coverage is more likely if a company has substantial transactions with the US. If this is true, then our sample will have a greater representation of companies with interactions with US, potentially reducing the within sample cross-sectional variation on this dimension. ${ }^{6}$

\footnotetext{
${ }^{6}$ Because of the way the sample firms in each country are chosen by S\&P, company characteristics may also vary across countries for a variety of reasons. For example, S\&P chooses to follow prominent companies in each country, and they may be drawn from different industries. Also, the decision to go public in each country is dependent on the institutional environment in that country. Since S\&P only follows public companies, the distribution of companies it draws from may vary from country to country. Finally, the average size of companies varies across countries. While we are unable to eliminate potential biases arising out of these sample selection issues, we attempt to address them in several ways. First, we include industry dummies in all our multiple regressions to control for industry effects. Second, we include size as a control variable in the regressions. Third, as a sensitivity check on our main results, we run regressions with country fixed effects to see if the results related to company level variables change significantly when country-level effects are controlled for.
} 
Table 1 provides the distribution of the overall Transparency score, and its three sub-components: Financial, Governance and Ownership. In the sample as a whole, there is considerable variation in the overall Transparency score from a high of 9 to a low of 1 . There is no company in our sample with a score of 10 . The mean (median) Transparency score is 5.90 ( 6 ). The mean (median) Financial disclosure score is 7.18 ( 7 ); the mean (median) Governance disclosure score is 4.95 ( 5 ) and the mean (median) Ownership disclosure score is 5.56 ( 6 ). Thus, on average, there is greater disclosure on financial performance, and less disclosure on ownership and governance, in our sample companies.

There are clearly country-specific patterns in the transparency scores. Table 2 provides descriptive statistics by country for the Transparency score. U.K has the highest mean score of 7.6 followed by France with 7.2. The lowest mean score is for Taiwan at 2.5. There is considerable variation in the range of scores in each country as well. For example, the scores in U.K range from 9 to 6 , from 7 to 5 in Japan, and from 6 to 5 in Hong Kong. In contrast, the scores in China range from 7 to 3 , in Thailand from 7 to 2, in India from 7 to 2 and in South Korea from 7 to 1. At the bottom end, the scores in Indonesia and Pakistan range from 5 to 3, and in Philippines and Taiwan, they range from 4 to 2 .

The mean overall transparency score for the Standard and Poor's U.S 500 companies, based on data not reported here, is $7.5 .^{7}$ The mean scores for S\&P U.S. 500 companies for the sub sections are Financial (8.1), Governance (8.2) and Ownership (5.7). The mean Transparency scores and subsection scores for Financial and Governance for the U.S are higher than for the all countries in our sample, with the exception of UK

\footnotetext{
${ }^{7}$ Of the 460 companies in the U.S. sample, 4 companies have a score of 6, 223 have 7, 230 have 8 , and 3 have 9. No company has a score of 10 .
} 
which has comparable scores to the U.S. This confirms our maintained hypothesis that the scores rely on an implicit U.S. benchmark.

Table 2 also provides descriptive statistics for the sub sections on Financial, Governance and Ownership. Countries that score high (low) on one of the dimensions also typically scores high (low) on the other two dimensions. However, there are clear exceptions to this pattern. For example, Germany scores high (8.0) on Financial transparency, but lower on governance disclosures (4.8) and ownership (5.0). Japan scores high on financial disclosures (7.6), and ownership disclosures (7.0), but low on governance disclosures (3.7). In general, in most countries, the average level of financial disclosure is higher than disclosures related to ownership and governance.

To check the validity of the disclosure measures of S\&P, we compare the country means for the S\&P scores with the CIFAR country index disclosure scores used in earlier research (for example La Porta et al. [1998], Hope [2003], Rajan and Zingales [1998], Bushman et al. [2002]). The CIFAR scores are based on disclosure data from 1995 and before. The Standard and Poor's data is based on more recent disclosure data. The CIFAR index is correlated 0.65 (significant at $1 \%$ level) with the S\&P overall transparency scores country means and 0.67 (significant at 1\% level) with the Financial subsection scores.

The S\&P survey has also been used in Durnev and Kim [2002]. They find that larger firms, firms with more R\&D expenditure, those with profitable investment opportunities and a greater reliance on external financing disclose more as measured by these scores. Firms with higher transparency ratings invest more and are valued higher. 
These relations are stronger in countries that are less investor friendly, suggesting that firms adapt to poor legal environments by increasing transparency.

\section{Measures of Interaction with the U.S. Markets}

We develop proxies to measure the extent of interaction with the U.S. in capital, product and labor markets. We develop both firm and country-level proxies for interaction since firms' disclosure practices may be associated with both these factors. In this section, we discuss the motivation for these variables and how they are created. In all cases data have been collected such that they correspond to the same period as the annual report used by $\mathrm{S} \& \mathrm{P}$ in the T\&D survey. Table 3 provides a summary of the variables, their definitions, and source.

\section{$\underline{\text { Financial Market Interaction Variables }}$}

We use three financial market interaction variables, one at the firm level, and two at the country level. As discussed in the hypothesis section, we expect all these three variables to have a positive coefficient.

\section{U.S. Listing}

The first financial market interaction measure we use is whether or not a firm is listed on a U.S. stock exchange. ${ }^{8}$ We identify whether a company is listed in the U.S.

\footnotetext{
${ }^{8}$ Prior research suggests that product market factors play a role in firms' listing decisions. Large companies and those with high proportion of overseas sales are most likely to list outside their home country and the level of exports to a given country influences the choice of foreign listing location. (Saudagaran [1988], Biddle and Saudagaran [1995]). In a survey of 78 Canadian companies listed in the U.S. or U.K. Mittoo [1992] finds that access to markets and increased marketability of products are the major benefits while complying with SEC requirements and legal listing fees are the major costs. Pagano et al. [2002] find that European firms that list abroad tend to be large and expand their exports after listing abroad more than those that do not. In addition firms that cross-list in the U.S. rely heavily on export markets both before and after listing, and tend to belong to the high-tech sector. As a result of these arguments, U.S. Listing can also be viewed as a proxy product market interaction, rather than for purely financial market interaction.
} 
either as direct equity or as a depositary receipt (ADR) using the Bank of New York ADR database, NYSE, NASDAQ and company annual reports. There are many levels of listing that a company can choose from while making a decision to list in the U.S. The variable takes the value 1 when the company is listed as equity, or level 2 or 3 ADR and 0 otherwise. Disclosure requirements are stricter for these types of listings. For other types of listing (Level 1 and Rule 144 A) disclosures requirements are weaker and voluntary. For example Level 1 and Rule 144 A ADR companies are not required to file Form 20-F statements. We check all the results for robustness when the variable takes the value 1 for any type of listing in the U.S.

\section{U.S. Equity Investment}

The proxy for country level capital market interaction is the extent of U.S. equity investment in that country through financial markets. We measure this as U.S. portfolio holdings of equity in the country in 2001 divided by the market capitalization of the country. These data are from the 2002 version of the Report on U.S Holdings of Foreign Long Term Securities published by the U.S Department of Treasury.

\section{U.S. FDI}

We use Foreign Direct Investment (FDI) from the U.S. as another proxy for the extent of U.S. investments at the country level. While portfolio investments are one way US investors make investments in a foreign market, foreign direct investment is an alternative way to invest in a foreign market. When U.S. multinationals operate in another country by making FDI investments, they bring with them US business practices, and frequently, information intermediaries such auditors and analysts. As a result of

However, to be consistent with prior accounting work, we treat U.S. Listing as a financial market interaction variable. 
these, local markets begin to be influenced by U.S. corporate practices, including disclosure and transparency. Domestic firms competing in an economy with a significant presence of U.S. multinationals are, therefore, likely to experience a greater demand from local factor and output markets to converge to U.S. practices, relative to firms in economies with little U.S. FDI. The variable is calculated as the stock of U.S. FDI divided by the GDP of the country for the relevant year. These data come from the U.S. Bureau of Economic Analysis.

\section{Product Market Interaction Variables}

We use two firm level variables (measured in two different ways) and one country level variable to proxy for the degree of interactions with the U.S. product market. As discussed earlier, we do not make a directional prediction on the signs of the coefficients of these variables.

\section{U.S. Exports}

Our first proxy for product market interaction is the extent of exports by the company to U.S. We examine the annual report geographical segment disclosures of all the companies and hand collect the extent of exports to the U.S. The variable is the ratio of exports to the U.S divided by total sales. The data is available for 628 companies in the sample. For the remaining companies it is not possible to estimate the export ratio to the U.S. because the data is presented either in an aggregate format such as total exports or as exports to U.S. and Europe.

Has U.S. Exports

As an alternative to the above variable, we also create an indicator variable Has U.S. Exports that takes the value 1 if we can determine that the company exports to the 
U.S. (even if we cannot determine the exact value). For the companies for which the export ratio data are available, this variable takes the value of 1 when U.S. export ratio is greater than 5\%. For the companies where export ratio data are not available we identify whether the company has U.S. exports based on the information from its annual report and description of operations at its website. We are able to identify this for 788 companies in the sample. This helps in increasing the number of observations used in the tests.

\section{U.S. Operations}

At the firm level, we also use the extent of a company's operations in the U.S. as a proxy for its degree of its product market interaction. While exporting goods produced abroad is one way for a foreign company to access the US product markets, another way to do the same is to locate operations in the US itself. We measure the extent of a company's U.S. operations using the share of assets of the company in the U.S. We hand collect data on share of assets in the U.S. from the geographical segment disclosures of companies. ${ }^{9}$ The variable measures the ratio of assets in the U.S. to the total assets of the company. This captures the effect of locating assets and people in the U.S that may have a different effect from exports, which can be done without any assets in the U.S at all. The data are available for 576 companies. The data are not available when geographical asset disclosures are not presented or when we cannot disaggregate the value of assets in the U.S. from a consolidated number such as assets in foreign countries.

\footnotetext{
${ }^{9}$ We use information from segment disclosures to develop the variables US Exports and US Operations. While geographical segment disclosure is not an item scored in the Transparency and Disclosure index by $\mathrm{S} \& \mathrm{P}$, segment disclosures (broken down by business line) is an item used in the scoring. Segment disclosures are therefore endogenous to the disclosure scores. This problem is somewhat mitigated in the indicator variables Has US Exports and Has US Operations since we use a mix of annual report disclosures and other public information to develop them.
} 


\section{Has U.S. Operations}

As an alternative to the above measure, we create an indicator variable that takes a value 1 if we identify the firm as having operations in the U.S. and zero otherwise. For the companies for which the asset ratio data are available, this variable takes the value of 1 when U.S. asset ratio is greater than $5 \%$. For the companies where asset ratio data are not available we identify whether the company has U.S. operations based on the information from its annual report and description of operations at its website. Hence we are able to construct this variable for all 794 companies. This is for the year 2000 or 2001 as applicable.

\section{U.S. Trade}

Trade with the U.S. is the proxy for the country level product market interaction. It is computed as the sum of exports and imports from U.S. to the country divided by GDP. The variable is for year 2000 or 2001 as applicable. The data is from the U.S. Bureau of Economic Affairs.

\section{$\underline{\text { Labor Market Interaction Variables }}$}

Labor market interactions are difficult to measure since public data on such interactions are not easily available. We use one measure of labor market interaction at the country level. We expect this measures to have a positive coefficient.

\section{Business Travel to U.S.}

A country-level proxy for the extent of labor market interaction with the U.S. is the extent of business travel from the country to the U.S. Business visitors have to possess a visa for entering the U.S. This data are provided by the Immigration and Naturalization Service (INS) in their annual handbook. The variable is the share of the 
country in the total number of business visas granted in the year 2000 or 2001 as

applicable for the particular country.

\section{Control Variables}

We control at the firm level and country level for the following factors that have been documented in earlier research as being associated with disclosure. Data are collected to match the year for which the annual report has been used by S\&P.

Size: We control for firm size using market capitalization of the company divided by the mean for the country ${ }^{10}$. We also use Assets and Sales (normalized in a similar way) for robustness checks. Data are for end of fiscal year 2000 or 2001 as applicable.

Analyst following: We identify the number of analysts following the company from the $\mathrm{I} / \mathrm{B} / \mathrm{E} / \mathrm{S}$ International database. We use the maximum number of analysts who issue oneyear ahead forecast. ${ }^{11}$ Analyst following is available for 785 companies of our sample.

For the 9 companies that $\mathrm{I} / \mathrm{B} / \mathrm{E} / \mathrm{S}$ does not cover, we assume that the analyst following is zero. Data are for the year of the annual report 2000 or 2001 as applicable.

Performance: Prior papers have examined the role of past performance on improved disclosure (for example Lang and Lundholm[1993], Miller [2002]). We control for past performance using past three-year market adjusted returns. Data are from the Compustat

\footnotetext{
${ }^{10}$ Since the sample companies are all constituents of the broad S\&P indices, they tend to be the largest in their home countries. There is a wide variation across countries in the size of the average market capitalization of the sample firms. At the top end, Switzerland and Germany have the largest companies in the sample with average market capitalization of 26.26 and 20.28 billion dollars respectively. At the other end are emerging market countries Pakistan and Thailand with average market capitalization of 294 and 656 million dollars respectively. To control for cross-country variation in firm size, we use the normalized size variable.

${ }^{11} \mathrm{We}$ also use data from the eleventh month of the fiscal year to calculate number of analysts following a company consistent with the methodology in Lang, Lins and Miller [2003] to check for robustness. Our measure of analyst following takes the maximum across the twelve months. The results are not sensitive to this difference in method.
} 
Global Vantage database and is for end of fiscal year 2000 or 2001 as applicable. Market returns are based on the Morgan Stanley capital index for that country for the same period. MCSI indices are available through Datastream.

Financial Leverage: Companies with greater degree of equity financing may disclose more in their public financial statements. We control for this using the debt/equity ratio. Data are from Compustat Global Vantage. Data are for 2000 or 2001 as applicable. $R \& D$ : We control for the research and development expenditure since Durnev and Kim [2002] find that companies with greater R\&D intensity also disclose more. The variable is computed as R\&D expenditure over Total Assets expressed in percentage. Data are from Worldscope. Following Durnev and Kim [2002] we assume that R\&D expenditure is zero when data are not available in Worldscope.

English Legal Origin: Many recent papers (for example La Porta et al. [1998]) highlight the role of legal systems concerning investor protection laws and show that country level differences in this are associated with hypothesized differences in financial markets. Results generally indicate that English Legal Origin is associated with higher levels of disclosure. To control for this potential effect, we use an indicator variable that measures whether or not the country has English legal origin.

Stock Return Co-movement: Similar disclosure practices can also be the result of similar economies in two countries. We use stock market co-movement to proxy for this similarity. The variable is the correlation of percent change in weekly stock market index between U.S. and the given country for the year 2000 or 2001 as applicable. Index data are from Morgan Stanley stock index from Datastream. 
All our tests include industry dummies based on Global Industry Classification System as described earlier. The industry distribution does not appear to vary systematically across countries. We face data limitations since data are not available for all the sample companies for all the variables. As a result fewer observations than the sample size of 794 are available to be used in the regression analysis. We are able to use 750 observations in our tests that use indicator variables for exports and operations and 555 observations in the tests that use actual values for exports and operations variables.

\section{Descriptive data for independent and control variables}

Table 4 provides descriptive statistics of the independent variables and control variables for the sample as a whole, and by country. Panel A of Table 4 provides descriptive statistics on firm level variables while Panel B provides information on country level variables.

Of the 794 sample companies, 186 are listed in the U.S either as equity or through a level 2 or level 3 ADR listing. ${ }^{12}$ U.K. has the most listed companies (48), followed by Japan (25), France (16), Netherlands (14), and Germany (12).

494 companies have exports to the U.S, the highest number coming from Japan (117) and the least from Philippines and Indonesia (1). The mean export ratios of the sample companies at the country level behave as may be expected. For our sample the mean export ratios at the top end are Switzerland (0.32), Sweden (0.30), Netherlands (0.29) and U.K (0.26) and at the bottom are China, Pakistan, Philippines and Thailand with zero exports to the U.S. 339 companies in our sample have operations in the U.S

\footnotetext{
12411 of the sample companies are listed in the U.S. if we consider all types of listing arrangements (including Level 1 and Rule 144 A ADR's).
} 
under our definition of the variable. These largest numbers are from United Kingdom (82), Japan (75), France (30) and Germany (26).

Since the sample companies tend to be the largest in their home countries, the average market capitalization of the sample is fairly large, $\$ 10.59$ billion. However, there is a wide variation across countries in the size of the average market capitalization of the sample firms. At the top end, Switzerland and Germany have the largest companies in the sample with average market capitalization of 26.26 and 20.28 billion dollars respectively. At the other end are emerging market countries Pakistan and Thailand with average market capitalization of 294 and 656 million dollars respectively.

The firms in the sample, on average, have performed well in terms of their stock returns. Recall that for the purpose of this computation, we use the return on the Morgan Stanley Country Index as the market return. The average market-adjusted return for the sample is $36 \%$ over the three years prior to the year in which disclosure was measured for these firms. Thus, the sample companies have significantly out-performed their respective broad country indices. There is, of course, some variation in this measure across countries. While companies in India, China, and Thailand have large average positive market-adjusted returns, companies in France, Netherlands, and Sweden have average negative market-adjusted returns.

The mean level of analyst coverage of our sample companies is quite high at 17.8 (range from 1 to 45). At the country level the highest average analyst following is in Germany (34) and Hong Kong (31). The least mean analyst following is for Pakistan (5) and India (11). 
Panel B of Table 4 presents descriptive statistics for country level market interaction variables. These data show that there is a wide variation across countries in terms of the level of market interaction with the U.S. The U.S. FDI measure (U.S. FDI/GDP) varies from a low of $0.32 \%$ in India to a high of $34.72 \%$ in Netherlands, and the U.S. Trade measure (U.S. Trade/GDP) varies from $1.88 \%$ in Spain to $42.66 \%$ in Malaysia. The U.S. Equity Investment variable (U.S. Equity/Market cap) varies from $0.41 \%$ in China to $17.63 \%$ in Netherlands. The stock return co-movement between the domestic market and the U.S. market varies from a low of -0.07 in Pakistan to a high of 0.81 in Germany. Eight of the 24 sample countries have English common law legal origin, while the remaining 16 have a different legal origin. Finally, countries also vary widely in their utilization of U.S. Business travel visas. Pakistan accounts for $0.2 \%$ of all U.S. Business visas, where as Japan accounts for $16.30 \%$.

In sum, there is a wide variation in our sample in the level of market interaction with the U.S., both at the firm and the country level. Next section examines whether this variation is associated with the variation in disclosures scores for the sample firms documented in Table 2.

\section{Results}

Table 5 provide univariate correlations between the variables. Transparency has a positive and significant correlation with U.S. Listing, U.S. Equity, U.S. FDI, U.S. Exports, Has U.S. Exports, U.S. Operations, Has U.S. Operations, Business Travel to U.S., Size, Analyst following, R\&D, English Legal origin, and Stock return comovement. Financial disclosure is also significantly positively correlated with the same set of 
variables except Legal Origin. US Trade is negatively correlated with the overall transparency measure and financial transparency. These correlations provide a preliminary indication that several of our U.S. market interaction variables and control variables are associated with disclosure scores of foreign firms.

There are also some significant correlations across the independent variables. Most notably, U.S. Exports and U.S. Operations (and the corresponding indicator variables) are highly correlated ( 0.79 and 0.69$)$. There is a large significant correlation between U.S. Equity Investment and U.S. FDI (0.61).

Given the magnitude of these correlations among the independent variables, it is difficult to draw inferences when we include all the variables in a multivariate regression. To address this issue, we perform factor analysis of all the market interaction variables (with varimax rotation) to identify common factors.

The factor analysis (not tabulated) allows us to identify two common factors. US Exports and US Operations (and the respective indicator variables) load on the same factor. We label this underlying construct as Operations Interaction. The two country level variables US Equity Investment and US FDI also load on a common factor. We label this Investment Interaction. None of the other market interaction variables load on common factors that have an eigenvalue greater than one and therefore we treat them as separate variables. This result is consistent with the observed correlation pattern. ${ }^{13}$ In the multivariate analysis we present results using these two factors and not the individual variables underlying the two factors.

\footnotetext{
${ }^{13} \mathrm{We}$ also repeat the factor analysis where we only include the four variables US Operations, US Exports, (their corresponding indicator variables), US Equity Investment and US FDI in the factor analysis. The results are invariant to this change in procedure.
} 


\section{Multivariate Analysis}

We use the firm and country level interaction measures in a regression analysis to examine the association between disclosure and economic interaction with the U.S. We include industry fixed effects and control variables. For the country level variables the effective sample size is only 24 . Further the independent variables could be clustered by country and the OLS standard errors are likely to be understated. We therefore follow the procedure in Rogers [1983] and Cohen, Polk and Vuolteenaho [2003] to correct the standard errors used in our tests. To test the robustness of these results, we also conduct a second set of tests where we remove all our country level measures and instead include country fixed effects.

We present results for the regression with the overall Transparency score as the dependent variable in Table 6. We present two different models. Model 1 includes the Operations Interaction factor formed using indicator variables for U.S. exports and U.S. operations (rather than actual magnitudes of these variables) leading to the maximum possible sample size, 750 observations. Model 2 alters Model 1 by using actual magnitude of U.S. exports and operations in forming the Operations Interactions factor, reducing the sample size to 555. All of these models include all the remaining firm and country level explanatory variables, and all the firm and country level controls.

Model 1 estimates show that Transparency is positively associated with the variables U.S. Listing, Investment Interaction, Operations Interaction, and Business Travel to U.S. ${ }^{14}$ The variable US Trade has an insignificant coefficient. Among the

\footnotetext{
${ }^{14}$ Throughout this section, we use a level of $5 \%$ or lower as a cut off for identifying statistically significant results.
} 
control variables, Performance, R\&D, English Legal Origin, and Stock Return Comovement are significantly associated with the overall Transparency score. Model 2 leads to identical inferences. The firm-level and country-level market interaction variables, along with the control variables, explain a significant portion $(59.8 \%$ in Model 1 and $58.6 \%$ in Model 2) of the variation in the overall Transparency scores.

The financial market interaction variables both at the company level and at the country level have a positive coefficient. The positive coefficient on U.S. Listing is not surprising. U.S. listing requires providing disclosures according to U.S standards. Thus companies that list on U.S. stock exchanges provide U.S style disclosures either due to listing regulations or due to self-selection by the listing companies. The results also show that Investment Interactions at the country level, through foreign direct investment or portfolio investment, are associated with similarities in disclosure.

At the firm level, the positive and significant coefficient on Operations Interaction indicates that such interaction is associated with U.S. style disclosure. At the country level, U.S. Trade does not have a statistically significant association with disclosure similarities.

Among the firm level control variables, there is a positive association between Performance and disclosure. Clearly, international firms that adopt US disclosure practices appear to be also good performers. Consistent with the result in Durnev and Kim [2002], R\&D is positively associated with disclosure. At the country level, English Legal origin and Stock Return Co-movement have a positive association with U.S. style disclosure practices. 


\section{Robustness checks}

\section{Analysis of Financial disclosure}

As discussed in Section 3, the overall Transparency score consists of not only the traditional financial statement disclosures, but also disclosures related to ownership and governance. To see whether the observed relationships between market interaction and disclosure similarities hold when one focuses on the core financial statement disclosures, we re-estimate the two models in Table 6 by substituting the overall Transparency score with its component, Financial disclosure.

We present the results in Table 7 . Results in Table 7 show that the associations with market interaction variables observed in Table 6 hold up when Financial disclosure is the dependent variable. U.S. Listing, Investment Interaction, Operations Interaction, Business Travel to U.S., are all significantly positively associated with the Financial disclosure scores. US Trade once again has an insignificant coefficient.

Among the control variables, R\&D, and Stock Return Co-movement continue to have significant positive coefficients. Performance has a positive coefficient significant at the 10\% (two-sided) level. Unlike in Table 6, Size and Analysts also have significant positive coefficients; English Legal Origin, which had a significant coefficient in Table 6, is not significant in Table 7.

We conclude from this analysis that the relation between market interaction variables and transparency is similar, whether one looks at the Overall Transparency or only Financial Transparency. There are, however, some differences in the relation between the control variables and the two types of Transparency scores. It is also interesting to note that English Legal Origin is significant when the dependent variable is 
the Overall Transparency and not with Financial disclosure scores. This suggests that, while sample companies from non-English legal origin countries are similar to their counterparts from English legal origin countries with respect to similarity with U.S. practices on the financial disclosure dimension, ownership and governance systems are stickier. $^{15}$

\section{Country Fixed Effects}

As the descriptive statistics in Table 4 show, there are systematic country patterns among the firm-level market interaction variables. Also, as discussed in the sample section, there are potentially unknown sample selection biases as a result of the way S\&P selects companies to include in its stock indices. To assess the sensitivity of our findings on company specific market interaction variables, we attempt to control for these patterns by including country-level variables in the multivariate analysis discussed above. We test the robustness of the results reported in the previous sections by removing the country level variables and instead using country fixed effects. For these tests, we present results using Model 1 in Tables 6 and $7 .{ }^{16}$ Table 8 reports the results for two regressions - with the overall Transparency score, and with Financial disclosure score, as the independent variable. As before, we also include industry fixed effects in these models to control for any industry-wide effects.

Results in Table 8 show that the earlier associations we observe between firmlevel market interaction variables and disclosure remain, when country fixed effects are

\footnotetext{
${ }^{15}$ This is consistent with Bushman et al. (2003). We thank a conference participant for bringing this to our attention.

${ }^{16}$ Results using Model 2 are very similar.
} 
included. U.S. Listing and Operations Interaction are positively associated with overall Transparency and Financial disclosure. We are not able to include the country level interaction variables in these country fixed effects regressions. Company level control variables also show significant associations with the transparency scores. Performance is also positively associated with disclosure in both the cases. R\&D is significantly associated with the overall transparency score, while Size is significantly associated with the Financial Transparency score. Both the models explain a large amount of the variation in the dependent variable, the adjusted R-square for Transparency being .75 and for financial disclosure being 0.62 .

\section{Definition of U.S. Listing}

In our analysis thus far, we use a strict definition of U.S. listing, i.e., listing as equity, level II and level III ADR. Under this definition, 186 firms in the sample are classified as U.S. Listed. However, another 225 sample firms are listed as Level I or Rule 144 A ADR's. These types of listings allow a company to raise funds in U.S. capital markets while not subjecting them to stricter SEC disclosure rules, but might have an impact on companies' voluntary disclosures. By not including these firms in our classification of U.S. Listed firms, we might be reaching erroneous conclusions on the relation between U.S. Listing and disclosure levels. Further, 96 of these 225 firms listed as Level 1 or Rule 144 A ADR's also have U.S. operations and 144 of the 225 have U.S. Exports. Therefore, the positive association between Interaction Factor 1 and disclosure we documented above might be in part due to the way we classified these firms for U.S. Listing. 
We repeat all the estimations in Tables 6 to 8 (results not reported in tables) to examine the effect of our U.S. Listing definition on our results using a more expansive definition of U.S. Listing that classifies firms with all types of listing as U.S. Listed. Results show that the association between U.S. Listing and disclosure becomes weaker under this weaker definition of listing. However, the results for all the other variables, including the Operations Interaction, remain unchanged.

We conclude that the positive association between disclosure and the Operations Interactions we documented in our earlier tests is not due to the firm level product market variables picking up the effect of a strict classification of U.S. listing. Also, a more expansive definition of U.S. listing only weakens the association between U.S. listing and disclosure.

\section{Excluding Japan from the sample}

Since Japan contributes the largest number of firms from any one country to the sample, we repeat the tests in Table 6, 7 and 8 after excluding these companies. The conclusions regarding the association between the market interaction variables and the disclosure scores remain unchanged when the sample excludes Japan.

\section{Discussion and Conclusions}

The empirical analysis presented in this paper examines the hypothesis that foreign companies that have significant interactions with U.S. product, labor, and financial markets are more likely to use U.S. disclosure practices relative to those that do not have such interactions. We test this hypothesis using a sample of 794 companies from 24 countries from Asia, Asia-Pacific and Europe. We use the Standard \& Poor's 
Transparency and Disclosure scores for these companies in our analysis. These scores use the US disclosure standards as an implicit benchmark, so they measure the degree of similarity of a company's disclosure practices to US practices. To measure the extent of market interaction with the US, we hand collect a variety of country and company level variables.

The results indicate that US listing by a company, the extent of investment interaction (through US FDI or Equity investments in the company's country), the extent of operations interaction (through a company's exports to or operations in the US), and the extent of business travel to the US from the company's country, are all positively associated with a company's disclosure scores. We do not find a significant association between a country's trade with the US and the disclosure scores of companies in that country. Our analysis controls for the previously documented association of disclosure with firm size, performance, analyst following, R\&D intensity, financial leverage, and country legal origin.

Our findings are consistent with the view that market interactions are associated with similarities in disclosure practices, either because countries choose to adopt regulations that lead to similarities in disclosure practices, or companies voluntarily adopt practices to facilitate market transactions. However, there are a number of potential limitations to our study that would warrant caution in interpreting our results. First, since we are able to present only correlational evidence, it is not possible to draw causal inferences. ${ }^{17}$ Second, since we only have one cross-section of data at a point in time, we

\footnotetext{
${ }^{17}$ In a clinical study of Infosys Technologies Limited, a leading software company based in India, Khanna and Palepu (2002) finds that intense global product market competition and the consequent need to attract talent (with global options) caused the company to adopt high quality corporate governance. Exposure to global capital markets was the result rather than the cause of improved governance standards.
} 
do not test convergence in a literal sense. Rather our analysis is about similarities in disclosure at a point in time. Third, our measure of disclosure does not allow us to distinguish between the quantity and the quality of disclosure, or between voluntary and mandatory disclosures. Fourth, because of data limitations, we rely on a sample preselected by Standard and Poor's for inclusion in the respective stock indices. Clearly this is not a random sample, leading to potentially unknown biases in the research design. Fourth, while our sample consists of several hundred firms, they are drawn from only 24 countries. Therefore, there are issues of cross-sectional correlation. This is of particular concern with respect to country level variables. While we have taken care to correct for the resulting biases in our statistical tests, one has to ultimately recognize the data limitations arising from the cross-country research design. Despite these limitations, we believe our study provides useful evidence on the relation between globalization and corporate disclosure practices.

Our study focuses only on a narrow aspect of the broader debate related to the impact of globalization of markets on the convergence of corporate governance practices. We study only one element of corporate governance, namely corporate disclosure and transparency. We also study interactions with only the United States markets. Much further work, therefore, remains to be done to resolve the debate regarding the relation between globalization and corporate governance convergence. 


\section{Appendix 1}

\section{Standard \& Poor's Transparency and Disclosure Survey Questions}

The T\&D scores provide a measure of a company's public disclosures. The scores are developed by searching company annual report for the inclusion of the 98 items listed below. The company receives one point when it provides information on an item. The results from the 98 questions below are converted into a percentage and then translated into scores from 1 to 10; for example a percentage of 11-20 gets a score of 2 and a percentage from 71-80 gets a score of 8. According to Standard \& Poor's the scores are designed so as to be unaffected by non-disclosure of items that are not applicable. The scores themselves are not released to the public by S\&P but the rankings are made available from the website: www.standardandpoors.com. The 98 items are grouped into three sub categories. The items considered for scoring are as follows:

Does the company in its annual accounts disclose: 


\section{Appendix 1 (continued)}

\begin{tabular}{|c|c|}
\hline & Financial Transparency \& Information Disclosure \\
\hline 1 & Its accounting policy? \\
\hline 2 & The accounting standards it uses for its accounts? \\
\hline 3 & accounts according to the local accounting standards? \\
\hline 4 & accounts according to an internationally recognized accounting standard (IAS/U.S. GAAP)? \\
\hline 5 & Its balance sheet according to international accounting standard (IAS/U.S. GAAP)? \\
\hline 6 & Its income statement according to international accounting standard (IAS/U.S. GAAP)? \\
\hline 7 & Its cash flow statement according to international accounting standard (IAS/U.S. GAAP)? \\
\hline 8 & a basic earnings forecast of any kind? \\
\hline 9 & a detailed earnings forecast? \\
\hline 10 & financial information on a quarterly basis? \\
\hline 11 & a segment analysis (broken down by business line)? \\
\hline 12 & The name of its auditing firm? \\
\hline 13 & a reproduction of the auditors' report? \\
\hline 14 & how much it pays in audit fees to the auditor? \\
\hline 15 & any non-audit fees paid to auditor? \\
\hline 16 & consolidated financial statements (or only the parent/holding co)? \\
\hline 17 & methods of asset valuation? \\
\hline 18 & information on method of fixed assets depreciation? \\
\hline 19 & a list of affiliates in which it holds a minority stake? \\
\hline 20 & a reconciliation of its domestic accounting standards to IAS/U.S. GAAP? \\
\hline 21 & The ownership structure of affiliates? \\
\hline 22 & details of the kind of business it is in? \\
\hline 23 & details of the products or services produced/provided? \\
\hline 24 & output in physical terms? (number of users etc.) \\
\hline 25 & characteristics of assets employed? \\
\hline 26 & efficiency indicators (ROA ROE etc.) \\
\hline 27 & any industry-specific ratios? \\
\hline 28 & a discussion of corporate strategy? \\
\hline 29 & any plans for investment in the coming year(s)? \\
\hline 30 & detailed information about investment plans in the coming year(s)? \\
\hline 31 & An output forecast of any kind? \\
\hline 32 & An overview of trends in its industry? \\
\hline 33 & Its market share for any or all of its businesses? \\
\hline 34 & a list/register of related party transactions? \\
\hline 35 & a list/register of group transactions? \\
\hline
\end{tabular}




\section{Appendix 1 (continued)}

\begin{tabular}{|c|c|}
\hline & Board and Management Structure and Process \\
\hline 1 & a list of board members (names)? \\
\hline 2 & details about directors (other than name/title)? \\
\hline 3 & details about current employment/position of directors provided? \\
\hline 4 & details about previous employment/positions provided? \\
\hline 5 & when each of the directors joined the board? \\
\hline 6 & classification of directors as an executive or an outside director? \\
\hline 7 & a named chairman listed? \\
\hline 8 & detail about the chairman (other than name/title)? \\
\hline 9 & details about role of the board of directors at the company? \\
\hline 10 & a list of matters reserved for the board? \\
\hline 11 & a list of board committees? \\
\hline 12 & the existence of an audit committee? \\
\hline 13 & the names on the audit committee? \\
\hline 14 & the existence of a remuneration/compensation committee? \\
\hline 15 & the names on the remuneration/compensation committee)? \\
\hline 16 & Existence of a nomination committee? \\
\hline 17 & the names on the nomination committee? \\
\hline 18 & the existence of other internal audit functions besides the Audit Committee? \\
\hline 19 & the existence of a strategy/investment/finance committee? \\
\hline 20 & the number of shares in the company held by directors? \\
\hline 21 & a review of the last board meeting? (e.g. minutes) \\
\hline 22 & whether they provide director training? \\
\hline 23 & the decision-making process of directors' pay? \\
\hline 24 & the specifics of directors' pay (e.g. the salary levels etc.)? \\
\hline 25 & the form of directors' salaries (e.g. cash,shares,etc.)? \\
\hline 26 & the specifics on performance-related pay for directors? \\
\hline 27 & the decision-making of managers' (not Board) pay? \\
\hline 28 & the specifics of managers' (not on Board) pay (e.g. salary levels etc.)? \\
\hline 29 & the form of managers' (not on Board) pay? \\
\hline 30 & the specifics on performance-related pay for managers? \\
\hline 31 & the list of the senior managers (not on the Board of Directors)? \\
\hline 32 & the backgrounds of senior managers disclosed? \\
\hline 33 & the details of the CEO's contract disclosed? \\
\hline 34 & the number of shares held by the senior managers disclosed? \\
\hline 35 & the number of shares held in other affiliated companies by managers? \\
\hline
\end{tabular}




\section{Appendix 1 (continued)}

\begin{tabular}{|l|l|}
\hline & Ownership Structure and Investor Relations \\
\hline 1 & number of issued and outstanding ordinary shares disclosed? \\
\hline 2 & number of issued and outstanding other shares disclosed (preferred, non-voting)? \\
\hline 3 & par value of each ordinary share disclosed? \\
\hline 4 & par value of each other shares disclosed (preferred, non-voting)? \\
\hline 5 & number of authorized but unissued \& outstanding ordinary shares disclosed? \\
\hline 6 & number of authorized but unissued \& outstanding other shares disclosed? \\
\hline 7 & par value of authorized but unissued \& outstanding ordinary Shares disclosed? \\
\hline 8 & par value of authorized but unissued \& outstanding other shares disclosed? \\
\hline 9 & top 1 shareholder? \\
\hline 10 & top 3 shareholders? \\
\hline 11 & top 5 shareholders? \\
\hline 12 & top 10 shareholders? \\
\hline 13 & description of share classes provided? \\
\hline 14 & review of shareholders by type? \\
\hline 15 & number and identity of shareholders holding more than 3\%? \\
\hline 16 & number and identity of shareholders holding more than $5 \% ?$ \\
\hline 17 & number and identity of shareholders holding more than 10\%? \\
\hline 18 & percentage of cross-ownership? \\
\hline 19 & existence of a Corporate Governance Charter or Code of Best Practice? \\
\hline 20 & Corporate Governance Charter / Code of Best Practice itself? \\
\hline 21 & details about its Articles of Association. (e.g. changes)? \\
\hline 22 & Voting rights for each voting or non-voting share? \\
\hline 23 & way that shareholders nominate directors to board? \\
\hline 24 & way shareholders convene an EGM? \\
\hline 25 & procedure for putting inquiry rights to the board? \\
\hline 26 & procedure for putting proposals at shareholders meetings? \\
\hline 27 & review of last shareholders meeting? (e.g.minutes) \\
\hline 28 & Calendar of important shareholders dates? \\
\hline & \\
\hline
\end{tabular}




\section{REFERENCES}

Ahearne, A.G., W.L. Griever and F.E. Warnock. 2001. "Information Costs and Home Bias: An Analysis of U.S. Holdings of Foreign Equities." Working Paper, Board of Governors of the Federal Reserve System.

Amir, E., T.S. Harris., and E.K. Venuti. 1993. "A Comparison of the Value-Relevance of U.S. versus Non-U.S. GAAP Accounting Measures using Form 20-F Reconciliations." Journal of Accounting Research 31: 230-75.

Bebchuk, L. A., and M.J. Roe. 1999. 'A Theory of Path Dependence in Corporate Ownership and Governance." Stanford Law Review 52(1): 127-170.

Biddle, G., and S. Saudagaran. 1995. "Foreign Listing Location: A Study of MNC's and Stock Exchanges in Eight Countries." Journal of International Business Studies 26: 31941.

Botosan, C. A. 1997. "Disclosure Level and Cost of Equity Capital." Accounting Review 72: $323-49$.

Bradshaw. M, B. Bushee and G. Miller. 2002. "Accounting Choice, Home Bias, and U.S. Investment in Non-U.S. Firms” Working Paper, Harvard Business School.

Bushman. R, J. and A. Smith. 2001. "Financial Accounting Information and Corporate Governance." Journal of Accounting and Economics 32 (1-3): 237-334

Bushman. R, J. Piotroski and A. Smith. 2003. "What Determines Corporate Transparency?" forthcoming Journal of Accounting Research.

Center for International Financial Analysis and Research (CIFAR) 1995. International Accounting and Auditing Trends. Vol I and II. Princeton, NJ, CIFAR Publications Inc.

Coffee, John C.,1999. "The Future as History: The Prospects for Global Convergence in Corporate Governance and its Implications."Northwestern University Law Review 93,641.

Cohen, Randolh B., Christopher Polk, and Tuomo Vuolteenaho. "The Value Spread." Journal of Finance, Volume 58, April 2003.

Darrough, M. 1993. "Disclosure Policy and Competition: Cournot and Bertrand." Accounting Review 68 (1993): 534-61.

Darrough, M. N. and N. M. Stoughton. "Financial Disclosure Policy in an Entry Game." Journal of Accounting and Economics (January 1990): 219-43. 
Durnev Art. and E. Han Kim. 2002. "To Steal or Not to Steal: Firm Attributes, Legal Environment, and Valuation.” Working Paper, University of Michigan Business School.

Gigler, F.1994. "Self-Enforcing Voluntary Disclosure." Journal of Accounting Research 32 (Autumn): 224-40.

Gilson, R. J. 2000. "Globalizing Corporate Governance: Convergence of Form or Function." Columbia University School of Law, Working Paper.

Hansmann, H., and R. Kraakman. 2001. "The End of History for Corporate Law." Georgetown Law Journal 89: 439-68.

Hayes. R. M., and R. Lundholm. 1996. " Segment Reportingto the Capital market in the Presence of a Competitor." Journal of Accounting Research 34: 261-79.

Healy. P, A. P. Hutton and K. Palepu. 1999. "Stock performance and Intermediation Changes Surrounding Sustained Increases in Disclosure." Contemporary Accounting Research 16:485-520.

Hope,O.K. 2002. " Disclosure practices, Enforcement of Accounting standards and Analysts' Forecast Accuracy: An International Study." Working paper, University of Toronto. forthcoming Journal of Accounting Research Conference issue.

U.S. Immigration and Naturalization Service, Statistical Yearbook of the Immigration and Naturalization Service, 1998, 1999. U.S. Government Printing Office: Washington .

Karolyi, G Andrew. 1998. "Why do Companies List Shares Abroad? A Survey of the Evidence and its Managerial Implications". Financial Markets, Institutions \& Instruments. Vol. 7 (1). p 1-60.

Khanna, T., J. Kogan., and K. Palepu., 2002. "Globalization and Corporate Governance Convergence? A Cross-Country Analysis”, Working Paper, Harvard Business School.

Khanna, T., and K. Palepu. 2001. "Product and Labor Market Globalization and Convergence of Corporate Governance: Evidence from Infosys and the Indian Software Industry”. Working Paper, Harvard Business School.

La Porta, R., Lpoez-de-Silanes, F., Shleifer, A. and Vishny. R. 1998. "Law and Finance." The Journal of Political Economy 106 (6): 1113-55.

Lang, M., K.V. Lins and D. Miller. 2003. “ADRs, Analysts, and Accuracy: Does Cross Listing in the U.S. Improve a Firm's Information Environment and Increase Market Value?" Journal of Accounting Research Vol 41(2): 317-362.

Lang, M., and R. Lundholm.1993 "Cross-Sectional Determinantsof Analysts ratings of Corporate Disclosures." Journal of Accounting Research 31: 246-71. 
Lang, M., and R. Lundholm. 1996. "Corporate Disclosure Policy and Analyst Behavior." Accounting review 71: 467-92.

Lang, M., J.S. Raedy, J. S. and M.H. Yetman. 2003. "How Representative are CrossListed Firms? An analysis of Firm Performance and Accounting Quality" Journal of Accounting Research Vol 41(2): 363-396.

Miller, G. 2002. “Earnings Performance and Discretionary Disclosure” Journal of Accounting Research, 40, 173-204.

Mittoo, U. 1992. "Managerial perceptions of the net benefits of foreign listing; Canadian evidence." Journal of International Financial Management and Accounting 4: 40-62.

Newman, P., and R. Sansing. 1993. "Disclosure Policies with Multiple Users." Journal of Accounting Research Spring: 92-112.

Pae, S. "Optimal Disclosure Policy in Oligopoly Markets.” Journal of Accounting Research 40 (June 2002): 901-32.

Pagano, Marco. Ailsa A. Roell, and Josef Zechner. 2002. "The Geography of Equity Listing: Why do Companies List Abroad?” Journal of Finance 57, 6: 2651-94.

Patel, Sandeep A, Amra Balic and Liliane Bwakira. 2002. "Measuring Transparency and Disclosure at Firm-level in Emerging Markets." Emerging Markets Review 3: 325-337.

Patel, Sandeep A. and Dallas, George S., "Transparency and Disclosure: Overview of Methodology and Study Results - United States" (October 16, 2002).

$\underline{\mathrm{http}: / / \mathrm{ssrn} . \mathrm{com} / \mathrm{abstract}=422800}$

Rogers, W.H., 1983, Analyzing Complex Survey Data, Rand Corporation Memorandum, Santa Monica, CA.

Rajan, R. and L. Zingales. 1998. "Financial Dependence and Growth.” American Economic Review 88: 559-86.

Saudagaran, S. 1988. "An Empirical Study of Selected Factors Influencing the Decision to List on Foreign Stock Exchanges." Journal of International Business Studies 19: 101127.

Shin, Y. C. 2002. "The Effect of Product Market Competition on Corporate Voluntary Disclosure Decisions" Working Paper, Tulane University.

Standard and Poor 2002. "Transparency and Disclosure Study - Frequently Asked Questions" Available at www.standardandpoors.com. 
Treasury Department and Federal Reserve Board. 2002. "Report on U.S. Holding of Foreign Long-Term Securities" available at www.ustreas.gov/fpis/flts.html

Verrecchia, R. E. 1983. "Discretionary Disclosure." Journal of Accounting and Economics 5: 179-94.

Verrecchia, R.E. 1990. "Endogenous Proprietary Costs through Firm Interdependence." Journal of Accounting and Economics 12: 245-50

Wagenhofer, A. 1990. "Voluntary Disclosure with a Strategic Opponent." Journal of Accounting and Economics March: 341-63. 


\section{Table 1}

Distribution of scores for overall Transparency and for subsections Financial, Governance and Ownership for the entire sample of 794 firms used in the study. The columns give the number of companies in the entire sample that have the particular score for each type of disclosure. TRANSPARENCY refers to the overall disclosure score using all the 98 questions given in Appendix 1. The presence of an item of disclosure gets one point. The total points are converted into a percentage and then translated into scores from 1 to 10 with a higher score indicating greater disclosure. For example a percentage of 81-90 will get a score of 9 while a percentage of 11-20 will get a score of 2. FINANCIAL disclosure scores are derived from the 35 questions in the sub section "Financial Transparency and Disclosure". GOVERNANCE disclosure scores are derived from the 35 questions in the category "Board and Management Structure and Processes". OWNERSHIP disclosure scores are derived from the 28 questions in the category "Ownership Structure and Investor Rights". The subsection scores are derived in the same way as the overall scores.

\begin{tabular}{ccccc}
\hline SCORES & TRANSPARENCY & FINANCIAL & GOVERNANCE & OWNERSHIP \\
\hline 1 & 1 & 0 & 52 & 17 \\
2 & 31 & 1 & 30 & 41 \\
3 & 26 & 0 & 158 & 45 \\
4 & 81 & 30 & 137 & 140 \\
5 & 115 & 64 & 105 & 192 \\
6 & 267 & 110 & 84 & 228 \\
7 & 157 & 243 & 89 & 46 \\
8 & 105 & 234 & 112 & 5 \\
9 & 11 & 94 & 25 & 0 \\
MEAN & 0 & 18 & 2 & 5.56 \\
\hline 10 & 5.90 & 7.18 & 5.95 & 6 \\
\hline & 6 & 7 & 5 & \\
\hline
\end{tabular}


Table 2

Descriptive Statistics for Transparency, Financial, Governance and Ownership scores.

\begin{tabular}{|c|c|c|c|c|c|c|c|c|c|}
\hline \multirow[b]{2}{*}{ Country } & \multirow[b]{2}{*}{$\mathrm{N}$} & \multicolumn{2}{|c|}{ TRANSPARENCY } & \multicolumn{2}{|c|}{ FINANCIAL } & \multicolumn{2}{|c|}{ GOVERNANCE } & \multicolumn{2}{|c|}{ OWNERSHIP } \\
\hline & & Mean & Median & Mean & Median & Mean & Median & Mean & Median \\
\hline Australia & 26 & 7.0 & 7 & 7.2 & 7 & 7.3 & 7 & 6.0 & 6 \\
\hline Belgium & 8 & 6.3 & 7 & 6.9 & 7 & 6.1 & 6 & 5.0 & 5 \\
\hline China & 17 & 5.2 & 6 & 7.4 & 7 & 4.1 & 4 & 4.3 & 4 \\
\hline Denmark & 6 & 5.5 & 5.5 & 7.7 & 7.5 & 4.3 & 5 & 4.5 & 4.5 \\
\hline France & 45 & 7.2 & 7 & 7.7 & 8 & 7.1 & 7 & 6.8 & 7 \\
\hline Germany & 32 & 6.1 & 6 & 8.0 & 8 & 4.8 & 4 & 5.0 & 5 \\
\hline Hong Kong & 23 & 5.4 & 5 & 7.0 & 7 & 4.5 & 5 & 4.2 & 4 \\
\hline India & 42 & 4.5 & 4 & 5.7 & 6 & 3.4 & 3 & 4.3 & 4 \\
\hline Indonesia & 13 & 4.2 & 4 & 6.3 & 6 & 2.2 & 2 & 4.4 & 4 \\
\hline Italy & 26 & 6.0 & 6 & 7.2 & 7 & 5.5 & 6 & 4.8 & 4.5 \\
\hline Japan & 150 & 6.0 & 6 & 7.6 & 8 & 3.7 & 4 & 7.0 & 7 \\
\hline Korea & 47 & 5.0 & 5 & 6.4 & 7 & 4.2 & 5 & 4.8 & 5 \\
\hline Malaysia & 51 & 5.0 & 5 & 6.2 & 6 & 3.6 & 3 & 6.1 & 6 \\
\hline Netherlands & 25 & 6.9 & 7 & 7.4 & 8 & 6.9 & 7 & 6.1 & 6 \\
\hline Pakistan & 10 & 4.2 & 4 & 5.9 & 6 & 2.3 & 2 & 4.6 & 4.5 \\
\hline Philippines & 9 & 3.3 & 3 & 5.8 & 6 & 1.7 & 1 & 2.7 & 3 \\
\hline Portugal & 7 & 6.1 & 6 & 6.9 & 7 & 4.7 & 4 & 6.7 & 7 \\
\hline Singapore & 11 & 6.9 & 7 & 7.9 & 8 & 5.6 & 6 & 6.8 & 7 \\
\hline Spain & 17 & 5.9 & 6 & 7.1 & 7 & 5.3 & 5 & 4.8 & 5 \\
\hline Sweden & 18 & 6.7 & 7 & 7.7 & 8 & 6.1 & 6 & 5.7 & 6 \\
\hline Switzerland & 17 & 6.2 & 6 & 7.8 & 8 & 5.8 & 6 & 4.9 & 5 \\
\hline Taiwan & 40 & 2.5 & 2 & 4.9 & 5 & 1.5 & 1 & 1.8 & 2 \\
\hline Thailand & 27 & 5.2 & 6 & 6.1 & 6 & 4.3 & 5 & 5.6 & 6 \\
\hline United Kingdom & 127 & 7.6 & 8 & 8.4 & 8 & 7.8 & 8 & 6.1 & 6 \\
\hline Total & 794 & 5.91 & 6 & 7.19 & 7 & 4.96 & 5 & 5.57 & 6 \\
\hline
\end{tabular}


Table 3

\section{Variable Definitions}

Variable Name

\section{Disclosure measures}

Transparency

Financial

\section{$\underline{\text { Financial Market Interaction Varables }}$}

\section{U.S. Listing}

\section{U.S. Equity Investment}

\section{U.S. FDI}

Investment Interaction (factor)

\section{$\underline{\text { Product Market Interaction Variables }}$}

U.S. Exports

Has U.S. Exports

U.S. Operations

Has U.S. Operations

U.S. Trade

Operations Interaction (factor)
Overall transparency score using all the 98 questions given in Appendix 1.

Disclosure score derived from 35 questions in the sub section "Financial Transparency and Disclosure" given in Appendix 1
Source
Standard and Poor's Transparency and Disclosure Survey

Standard and Poor's Transparency and Disclosure Survey
Whether a firm is listed in the U.S. either as equity or as level 2 or level 3 ADR.

Stock of U.S. Equity Investment in given country divided by country's market capitalization in \%.

Stock of U.S. Direct Investment divided by GDP of country in \%.

Variable representing U.S FDI and U.S. Equity Investment created from factor analysis of the economic interaction variables.
Bank of New York ADR directory at www.adrbny.com, NYSE, NASDAQ and company annual reports

Report on US Holding of Foreign Securities, Division of International Finance, Board of Governors of the Federal Reserve System: www. Ustreas.gov/fpis/flts.html

Bureau of Economic Analysis at www.bea.gov.
Ratio of export sales to U.S to total sales of the company.

Indicator variable equals 1 if firm has exports to the U.S. and 0 otherwise.

Ratio of assets in U.S. to total assets of the company.

Indicator variable equals 1 if the firm has operations in the U.S. and 0 otherwise.

U.S. Trade (Exports+Imports)/GDP, in \%. Variable representing U.S Exports and U.S. Operations (and the corresponding indicator variables) created from factor analysis of the economic interaction variables.
Annual report and company website.

Annual report and company website.

Annual report and company website.

Annual report and company website. Bureau of Economic Analysis at www.bea.gov. 
Table 3 (continued)

Variable Definitions

$\begin{array}{ll}\text { Variable Name Description } & \text { Source }\end{array}$

\section{$\underline{\text { Labor Market Interaction Variable }}$}

\# of Business Visas granted to Country in category/total \# of visas

Business Travel to U.S. issued in that category in \%. INS Yearbook

\section{$\underline{\text { Control Variables }}$}

Size

Analyst Following

Performance

Financial Leverage

R \& D
Market capitalization normalized by country mean

Compustat Global Vantage

Number of analysts issuing forecasts on $\mathrm{I} / \mathrm{B} / \mathrm{E} / \mathrm{S}$

$\mathrm{I} / \mathrm{B} / \mathrm{E} / \mathrm{S}$

3 year market adjusted stock return performance

Debt/equity ratio

Firm research and development

expenditure over total assets * $100 \quad$ Worldscope

Correlation between weekly stock market index changes in percentage Stock Return Co-movement between a country and U.S. English Legal Origin Legal origin of the country
Compustat Golbal Vantage

Compustat Golbal Vantage
Datastream

La Porta et al. (1998) 
Table 4

\section{Descriptive statistics}

Panel A: Descriptive statistics of firm level interaction measures and control variables ${ }^{1}$. The table is presented in alphabetical order by country. See Table 3 for variable definitions.

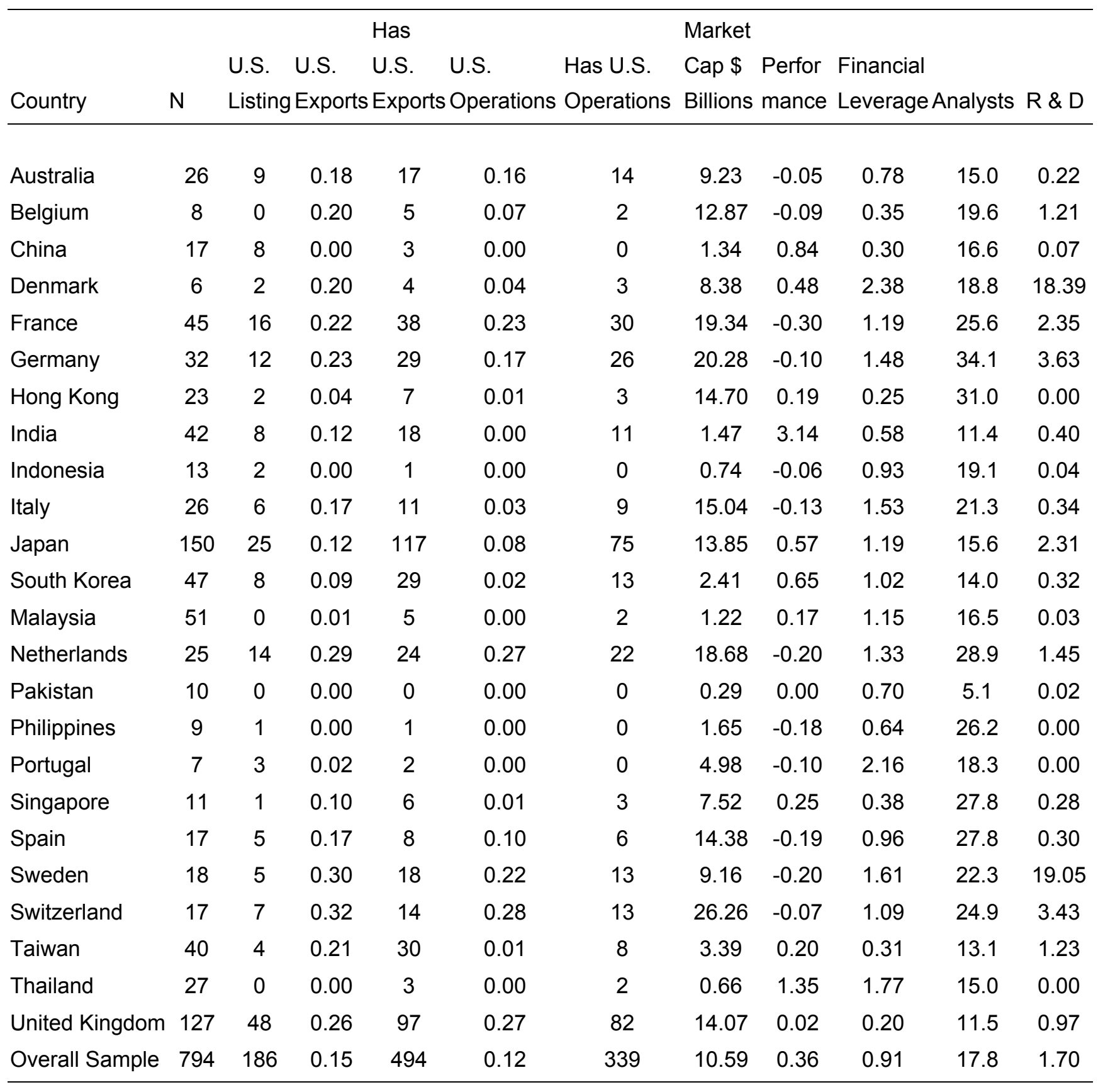

${ }^{1}$ The numbers in all columns except for U.S. Listing, Has U.S. Exports and Has U.S. Operations are the mean values for the companies for which data is available. For U.S. Listing, Has U.S. Exports and Has U.S. Operations, the values represent the number of companies in each country that have the respective feature. Market Cap is the average market capitalization in billions of U.S. dollars as of relevant year for the companies in the sample for the given country. In the regression analysis we have normalized the firm market capitalization with this country mean. 


\section{Table 4 (continued)}

Panel B: Descriptive statistics of country level interaction and control variables. The table is presented in alphabetical order by country. See Table 3 for variable definitions.

\begin{tabular}{|c|c|c|c|c|c|c|}
\hline \multirow[b]{3}{*}{ Country } & \multirow[b]{3}{*}{ U.S. FDI \% } & \multicolumn{4}{|c|}{ Business } & \multirow{3}{*}{$\begin{array}{c}\text { Stock } \\
\text { Returns } \\
\text { Comovement }\end{array}$} \\
\hline & & \multicolumn{2}{|l|}{ U.S. Equity } & \multicolumn{2}{|c|}{ Visitors to English Legal } & \\
\hline & & Investment \% & S. Trade $\%$ & U.S \% & Origin & \\
\hline Australia & 8.98 & 9.73 & 4.81 & 1.78 & 1 & 0.59 \\
\hline Belgium & 8.88 & 4.64 & 10.30 & 0.69 & 0 & 0.59 \\
\hline China & 0.91 & 0.41 & 10.76 & 1.31 & 0 & 0.35 \\
\hline Denmark & 4.03 & 6.99 & 3.09 & 0.52 & 0 & 0.63 \\
\hline France & 2.95 & 7.79 & 3.85 & 3.72 & 0 & 0.74 \\
\hline Germany & 3.33 & 5.69 & 4.83 & 5.43 & 0 & 0.81 \\
\hline Hong Kong & 16.30 & 4.85 & 15.94 & 0.37 & 1 & 0.60 \\
\hline India & 0.32 & 4.66 & 3.23 & 1.00 & 1 & 0.34 \\
\hline Indonesia & 6.22 & 5.76 & 9.33 & 0.22 & 0 & -0.07 \\
\hline Italy & 2.19 & 4.40 & 3.10 & 2.34 & 0 & 0.63 \\
\hline Japan & 1.55 & 5.44 & 4.44 & 16.30 & 0 & 0.28 \\
\hline South Korea & 1.95 & 17.28 & 14.90 & 2.20 & 0 & 0.43 \\
\hline Malaysia & 8.63 & 2.23 & 42.66 & 0.26 & 1 & 0.26 \\
\hline Netherlands & 34.72 & 17.63 & 7.64 & 1.89 & 0 & 0.71 \\
\hline Pakistan & 0.80 & 1.30 & 4.71 & 0.20 & 1 & 0.08 \\
\hline Philippines & 3.64 & 2.63 & 30.24 & 0.63 & 0 & 0.06 \\
\hline Portugal & 1.67 & 6.31 & 2.43 & 0.34 & 0 & 0.42 \\
\hline Singapore & 27.78 & 13.95 & 40.09 & 0.35 & 1 & 0.39 \\
\hline Spain & 3.34 & 6.45 & 1.88 & 1.33 & 0 & 0.69 \\
\hline Sweden & 8.55 & 7.42 & 5.93 & 0.98 & 0 & 0.70 \\
\hline Switzerland & 25.42 & 9.71 & 7.87 & 1.09 & 0 & 0.73 \\
\hline Taiwan & 2.52 & 7.95 & 20.93 & 1.16 & 0 & 0.32 \\
\hline Thailand & 5.31 & 6.57 & 18.42 & 0.24 & 1 & 0.20 \\
\hline United Kingdom & 17.47 & 13.57 & 5.75 & 15.79 & 1 & 0.77 \\
\hline
\end{tabular}


Table 5: Univariate Correlations

Please see Table 3 for variable definitions. The numbers marked with * are significant at $5 \%$ level (two tailed). The numbers shown are Pearson correlations. Spearman correlations not shown for brevity are consistent with Pearson correlations.

\begin{tabular}{|c|c|c|c|c|c|c|c|c|c|c|c|c|c|c|c|c|c|}
\hline & $\begin{array}{l}\text { Overall } \\
\text { Transpar } \\
\text { ency } \\
\end{array}$ & Financial & $\begin{array}{l}\text { US } \\
\text { IListing }\end{array}$ & $\begin{array}{l}\text { US } \\
\text { Equity } \mathrm{F}\end{array}$ & $\begin{array}{l}\text { US } \\
\text { FDI }\end{array}$ & $\begin{array}{l}\text { Has } \\
\text { US } \\
\text { Exports }\end{array}$ & $\begin{array}{l}\text { US } \\
\text { Exports }\end{array}$ & $\begin{array}{l}\text { Has US } \\
\text { Operations }\end{array}$ & $\begin{array}{l}\text { US } \\
\text { Operati } \\
\text { ons }\end{array}$ & $\begin{array}{l}\text { US } \\
\text { Trade }\end{array}$ & $\begin{array}{l}\text { Business } \\
\text { Travel to } \\
\text { US }\end{array}$ & Size & Analysts & $\begin{array}{l}\text { Financial } \\
\text { Leverage }\end{array}$ & $\begin{array}{l}\text { Perform } \\
\text { ance }\end{array}$ & $\mathrm{R} \& \mathrm{D}$ & $\begin{array}{l}\text { English } \\
\text { Legal } \\
\text { Origin } \\
\end{array}$ \\
\hline $\begin{array}{l}\text { Overall } \\
\text { Transparency }\end{array}$ & 1 & & & & & & & & & & & & & & & & \\
\hline Financial & $0.82^{*}$ & 1 & & & & & & & & & & & & & & & \\
\hline US Listing & $0.38^{*}$ & $0.42^{*}$ & 1 & & & & & & & & & & & & & & \\
\hline US Equity & $0.37^{*}$ & $0.25^{*}$ & $0.21^{*}$ & 1 & & & & & & & & & & & & & \\
\hline US FDI & $0.43^{*}$ & $0.31^{*}$ & $0.19^{*}$ & $0.61^{*}$ & 1 & & & & & & & & & & & & \\
\hline Has US Exports & $0.25^{\star}$ & $0.25^{\star}$ & $0.19^{*}$ & $0.23^{*}$ & $0.10^{*}$ & 1 & & & & & & & & & & & \\
\hline US Exports & $0.32^{*}$ & $0.28^{*}$ & $0.34^{*}$ & $0.34^{*}$ & $0.28^{*}$ & $0.66^{*}$ & 1 & & & & & & & & & & \\
\hline $\begin{array}{l}\text { Has US } \\
\text { Operations }\end{array}$ & $0.43^{*}$ & $0.41^{*}$ & $0.29^{*}$ & $0.23^{*}$ & $0.20^{*}$ & $0.69^{*}$ & $0.63^{*}$ & 1 & & & & & & & & & \\
\hline US Operations & $0.48^{*}$ & $0.39^{*}$ & $0.29^{*}$ & $0.38^{*}$ & $0.36^{*}$ & $0.56^{*}$ & $0.79^{*}$ & $0.70^{*}$ & 1 & & & & & & & & \\
\hline US Trade & $-0.35^{*}$ & $-0.34^{*}$ & $-0.18^{*}$ & $-0.10^{*}$ & $0.13^{*}$ & $-0.30^{*}$ & $-0.25^{\star}$ & $-0.31^{*}$ & $-0.26^{*}$ & 1 & & & & & & & \\
\hline $\begin{array}{l}\text { Business Travel } \\
\text { to US }\end{array}$ & $0.42^{*}$ & $0.48^{*}$ & 0.07 & $0.15^{*}$ & 0.04 & $0.27^{*}$ & $0.18^{*}$ & $0.26^{*}$ & $0.27^{*}$ & $-0.44^{*}$ & 1 & & & & & & \\
\hline Size & $0.14^{*}$ & $0.20^{*}$ & $0.33^{*}$ & 0 & 0 & 0.02 & 0.03 & $0.09^{*}$ & 0.03 & 0 & 0 & 1 & & & & & \\
\hline Analysts & $0.14^{*}$ & $0.17^{*}$ & $0.21^{*}$ & $-0.08^{*}$ & $0.13^{*}$ & $0.08^{*}$ & 0.04 & $0.16^{*}$ & 0.02 & 0.01 & $-0.27^{*}$ & $0.29^{*}$ & 1 & & & & \\
\hline $\begin{array}{l}\text { Financial } \\
\text { Leverage }\end{array}$ & -0.02 & -0.04 & $-0.08^{*}$ & -0.06 & -0.07 & -0.02 & -0.03 & 0.02 & -0.01 & -0.01 & -0.04 & -0.05 & 0.05 & 1 & & & \\
\hline Performance & -0.04 & -0.06 & -0.01 & -0.06 & $-0.09^{*}$ & 0 & 0.02 & -0.03 & -0.06 & -0.02 & -0.02 & 0.07 & $-0.09^{*}$ & -0.04 & 1 & & \\
\hline$R \& D$ & $0.09^{*}$ & $0.10^{*}$ & $0.16^{*}$ & -0.02 & -0.01 & $0.14^{*}$ & $0.09^{*}$ & $0.15^{\star}$ & $0.08^{*}$ & $-0.08^{*}$ & 0.01 & $0.1^{*}$ & $0.16^{*}$ & -0.04 & -0.01 & 1 & \\
\hline $\begin{array}{l}\text { English Legal } \\
\text { Origin }\end{array}$ & $0.17^{*}$ & 0.03 & -0.02 & $0.13^{*}$ & $0.39^{*}$ & $-0.23^{*}$ & -0.03 & $-0.09^{*}$ & 0.05 & $0.30^{*}$ & 0 & 0 & $-0.28^{*}$ & $-0.10^{*}$ & $0.07^{*}$ & $-0.12^{*}$ & 1 \\
\hline $\begin{array}{l}\text { Stock Return } \\
\text { Comovement }\end{array}$ & $0.58^{*}$ & $0.47^{*}$ & $0.26^{*}$ & $0.49^{*}$ & $0.52^{*}$ & $0.29^{*}$ & $0.42^{*}$ & $0.38^{*}$ & $0.48^{*}$ & $-0.38^{*}$ & $0.12^{*}$ & 0 & $0.24^{*}$ & -0.04 & $-0.12^{*}$ & $0.08^{*}$ & $0.12^{*}$ \\
\hline
\end{tabular}




\section{Table 6}

\section{Overall Transparency and Interaction with U.S Markets}

Regression estimates of overall Transparency score on company and country level U.S. interaction variables, control variables and industry dummies. All variables are defined in Table 3. Industry dummies are based on Global Industry Classification Standards (GICS). In Model 1, the indicator variables for U.S. exports and U.S. operations are used in the factor analysis to create the Operations Interaction variable while in Model 2 the actual magnitude of U.S. exports and operations are used. t-stats (in parentheses) are robust to heterosckedasticity and are corrected for clustering by country. $*$, ** denote two sided significance at the $5 \%$ and $1 \%$ levels respectively. $\mathrm{N}$ refers to the number of observations used in each of the models.

\begin{tabular}{|c|c|c|c|c|}
\hline & \multicolumn{2}{|l|}{ Model 1} & \multicolumn{2}{|l|}{ Model 2} \\
\hline Industry Dummies & Included & & Included & \\
\hline US LISTING & 0.63 & $(4.27)^{\star *}$ & 0.45 & $(3.08)^{\star *}$ \\
\hline INVESTMENT INTERACTION & 0.21 & $(3.97)^{\star *}$ & 0.21 & $(2.98)^{\star \star}$ \\
\hline OPERATIONS INTERACTION & 0.22 & $(4.68)^{\star \star}$ & 0.25 & $(3.32)^{\star \star}$ \\
\hline US TRADE & -0.01 & $(-0.41)$ & 0.00 & $(-0.1)$ \\
\hline BUSINESS TRAVEL TO US & 0.08 & $(4.61)^{\star \star}$ & 0.09 & $(5.18)^{\star \star}$ \\
\hline SIZE & 0.01 & $(0.2)$ & 0.03 & $(0.88)$ \\
\hline ANALYSTS & 0.02 & $(1.4)$ & 0.02 & $(1.64)$ \\
\hline FINANCIAL LEVERAGE & 0.01 & $(0.77)$ & 0.00 & $(0.22)$ \\
\hline PERFORMANCE & 0.03 & $(2.97)^{\star *}$ & 0.03 & $(3.49)^{\star *}$ \\
\hline R\&D & 0.01 & $(4.08)^{* *}$ & 0.01 & $(1.94)$ \\
\hline ENGLISH LEGAL ORIGIN & 0.43 & $(3.82)^{* *}$ & 0.32 & $(2.43)^{*}$ \\
\hline STOK RETURN COMOVEMENT & 2.00 & $(2.78)^{\star *}$ & 2.17 & $(2.93)^{\star *}$ \\
\hline CONSTANT & 3.43 & $(5.72)^{\star *}$ & 3.15 & $(4.92)^{\star *}$ \\
\hline $\mathrm{N}$ & 750 & & 555 & \\
\hline ADJ R2 & 0.598 & & 0.5863 & \\
\hline
\end{tabular}




\section{Table 7}

\section{Financial Disclosures and Interaction with U.S Markets}

Regression estimates of overall Transparency score on company and country level U.S. interaction variables, control variables and industry dummies. All variables are defined in Table 3. Industry dummies are based on Global Industry Classification Standards (GICS). In Model 1, the indicator variables for U.S. exports and U.S. operations are used in the factor analysis to create the Operations Interaction variable while in Model 2 the actual magnitude of U.S. exports and operations are used. t-stats (in parentheses) are robust to heterosckedasticity and are corrected for clustering by country. $*$, ** denote two sided significance at the $5 \%$ and $1 \%$ levels respectively. $\mathrm{N}$ refers to the number of observations used in each of the models.

\begin{tabular}{|c|c|c|c|c|}
\hline & Model 1 & & Model 2 & \\
\hline Industry Dummies & Included & & Included & \\
\hline US LISTING & 0.71 & $(6.45)^{\star \star}$ & 0.66 & $(6.34)^{\star \star}$ \\
\hline INVESTMENT INTERACTION & 0.11 & $(2.06)^{*}$ & 0.10 & $(2.08)^{*}$ \\
\hline OPERATIONS INTERACTION & 0.16 & $(2.49)^{*}$ & 0.12 & $(2.32)^{\star}$ \\
\hline US TRADE & 0.00 & $(0.2)$ & 0.00 & $(0.6)$ \\
\hline BUSINESS TRAVEL TO US & 0.09 & $(8.72)^{* *}$ & 0.09 & $(10.04)^{* *}$ \\
\hline SIZE & 0.04 & (1.29) & 0.05 & $(2.31)^{*}$ \\
\hline ANALYSTS & 0.02 & $(2.31)^{*}$ & 0.02 & $(2.52)^{\star}$ \\
\hline FINANCIAL LEVERAGE & 0.00 & $(-0.32)$ & 0.00 & $(-0.4)$ \\
\hline PERFORMANCE & 0.02 & $(1.85)$ & 0.02 & $(1.88)$ \\
\hline R\&D & 0.01 & $(1.92)$ & 0.02 & $(5.02)^{* *}$ \\
\hline ENGLISH LEGAL ORIGIN & 0.00 & $(0.01)$ & -0.05 & $(-0.23)$ \\
\hline STOK RETURN COMOVEMENT & 1.29 & $(3.15)^{\star *}$ & 1.33 & $(3.33)^{* *}$ \\
\hline CONSTANT & 5.21 & $(13.83)^{* *}$ & 4.79 & $(11.83)^{\star *}$ \\
\hline$N$ & 750 & & 555 & \\
\hline ADJ R2 & 0.5516 & & 0.5313 & \\
\hline
\end{tabular}




\section{Table 8}

\section{Tests using country fixed effects}

Regression estimates of overall Transparency score (Model 1) and sub section scores for Financial disclosures (Model 2) on all firm level U.S. interaction variables, country fixed effects, industry fixed effects and firm level control variables. All variables are defined in Table 3. The indicator variables for U.S. exports and U.S. operations are used in the factor analysis to create the Operations Interaction variable. Industry dummies are based on Global Industry Classification Standards (GICS). t-stats (in parentheses) are robust to heterosckedasticity and are corrected for clustering by country. ${ }^{*}, * *$ denote two sided significance at the $5 \%$ and $1 \%$ levels respectively. $N$ refers to the number of observations used in each of the models.

\begin{tabular}{|c|c|c|}
\hline & $\begin{array}{l}\text { OVERALL } \\
\text { TRANSPARENCY }\end{array}$ & FINANCIAL \\
\hline Industry Dummies & Included & Included \\
\hline Country Dummies & Included & Included \\
\hline US LISTING & $0.60 \quad(4.7)^{\star *}$ & $0.70 \quad(6.93)^{\star *}$ \\
\hline OPERATIONS INTERACTION & $0.17 \quad(4.58)^{* *}$ & $\begin{array}{ll}0.16 & (2.47)^{*}\end{array}$ \\
\hline SIZE & $0.04 \quad(1.42)$ & $0.07 \quad(3.01)^{\star *}$ \\
\hline ANALYSTS & $0.01 \quad(1.56)$ & $0.00 \quad(0.78)$ \\
\hline FINANCIAL LEVERAGE & $0.00 \quad(-0.3)$ & $-0.01 \quad(-0.79)$ \\
\hline PERFORMANCE & $0.03(10.6)^{* *}$ & $0.02 \quad(2.35)^{*}$ \\
\hline$R \& D$ & $0.01 \quad(2.66)^{*}$ & $\begin{array}{ll}0.00 & (0.72)\end{array}$ \\
\hline CONSTANT & $4.62(18.56)^{\star *}$ & $7.02(34.02)^{* *}$ \\
\hline$N$ & 750 & 750 \\
\hline ADJ R2 & 0.7563 & 0.6174 \\
\hline
\end{tabular}

